\title{
ISLAM DAN POLITIK ORDE LAMA; \\ “DINAMIKA POLITIK ISLAM PASCA KOLONIAL \\ SEJAK KEMERDEKAAN SAMPAI AKHIR KEKUASAAN \\ SOEKARNO”
}

\author{
Jainuddin, M. Hum. \\ Institut Agama Islam (IAI) Muhammadiyah Bima \\ Jln. Anggrek No. 16 Ranggo Na'e Kota Bima \\ Jainuddin.ptais015@gmail.com
}

\section{Abstrak}

Setelah mengeluarkan dekret, Soekarno yang sudah terobsesi untuk menjadi penguasa mutlak di Indonesia, memaksa pembubaran partai Masyumi pada 17 Agustus 1960. Pemberlakuan Demokrasi Terpimpin oleh Soekarno ternyata menimbulkan respon yang beragama dari kalangan partai Islam. Ahmad syafi'i ma'arif membagi era Demmokrasi Terpimpin ini menjadi periode kristalisasi dan Periode Kolaborasi. Periode kristalisasi ditandai dengan pemilihan kawan dan lawan, pendukung dan oposisi terhadap kebijakan Soekarno tersebut. Sementara periode kolaborasi ditandai dengan kerja sama partai-partai Islam yang ikut bersama demokrasi terpimpin, termasuk dengan komunis, yang merupakan salah satu pilar penyangganya. Islam dipandang sebagai salah satu unsur Nasakom dengan NU sebagai wakil utamanya, Partai-partai Islam yang lain dalam menghadapi berbagai isu politik lebih banyak meniru gaya NU sebagai kekuatan Islam terbesar saat itu.

Keywords: Politik Islam, Orde Lama 


\section{Pendahuluan}

Berakhirnya era demokrasi liberal sejak keluarnya Dekret Presiden 1959 menandai bermulanya era baru politik indonesia yang disebut Demokrasi Terpimpin. Ada beberapa alasan bagi Soekarno mengeluarkan dekritnya. Pertama, anjuran presiden dan pemerintah untuk kembali ke UUD 1945 pada 22 Juni 1959 tidak memperoleh jawaban dari konstituante; kedua, sebagian besar anggota konstituante menyatakan walk out dari sidang, sehingga tugas-tugas mereka tak bisa terselesaikan; ketiga, keadaan demikian menimbulkan bahaya bagi ketatanegaraan dan keselamatan Negara. Akhirnya pada 5 Juli 1959 Soekarno mengeluarkan dekrit presiden yang isinya adalah menetapkan pembubaran konstituante, kembali kepada UUD 1945 sebagai konstitusi negara, membentuk Majelis Permusyawaratan rakyat Sementara (MPRS) dan Dewan Pertimbangan Agung Sementara (DPAS). ${ }^{1}$

Era ini dapat dianggap sebagai masa-masa sulit bagi partai Islam. Setelah mengeluarkan dekret, Soekarno yang sudah terobsesi untuk menjadi penguasa mutlak di Indonesia, memaksa pembubaran partai Masyumi pada 17 Agustus 1960. Pemberlakuan Demokrasi Terpimpin oleh Soekarno ternyata menimbulkan respon yang beragama dari kalangan partai Islam. Ahmad syafi'i ma'arif membagi era Demmokrasi Terpimpin ini menjadi periode kristalisasi (hingga Desember 1960) dan Periode Kolaborasi (hingga Pecahnya pemberontakan G-30-S/PKI). ${ }^{2}$

${ }^{1}$ H.A. Notosoetardjo, Proses kembali kepada Jiwa Proklamasi 1945; Apakah Demokrasi Terpimpin itu? (Jakarta: Lembaga Penggali dan Penghimpun Sedjarah Revolusi Indonesia, 1964), hlm, xi-xii

2 Lihat Tesis MA-nya pada University of Ohio, Amerika Serikat berjudul Islamic under Guided Democracy in Indonesia, terj. Islam dan Politik di Indonesia Pada Demokrasi Terpimpin (1959-1965) (Yogyakarta: IAIN Sunan Kalijaga Press, 1988) lihat Juga dalam Muhammad Iqbal dan Amin Husein Nasution, Pemikiran Politik Islam Dari Masa klasik Hingga Indonesia Kontemporer (Jakarta: Kencana Prenada Media Group, 2010), hlm, 268

Sangaji Jurnal Pemikiran Syariah dan Hukum 
Periode kristalisasi ditandai dengan pemilihan kawan dan lawan, pendukung dan oposisi terhadap kebijakan Soekarno tersebut. Sementara periode kolaborasi ditandai dengan kerja sama partaipartai Islam yang ikut bersama demokrasi terpimpin, termasuk dengan komunis, yang merupakan salah satu pilar penyangganya.

Tujuan pokok dalam tulisan ini adalah mencoba melihat realitas politik yang tercermin dalam tingkah laku politik praktis partai-partai Islam pada demokrasi terpimpin (1959-1965), suatu periode singkat dalam sejarah modern indonesia, tapi cukup penting dan genting bila di tempatkan dalam suatu perspektif sejarah perjuangan partai-partai Islam di indonesia. Dalam perjalanan sejarah perpolitikan, umat Islam yang dinyatakan sebagai mayoritas, namun posisi politik Islam sungguh sangat lemah. Partai-partai Islam pada masa itu merupakan kelomppok minoritas dalam lembaga-lembaga kenegaraan. Sebagai kelompok minoritas mereka hanya mengambil peran-peran pinggiran dalam memberikan corak Islam pada perkembangan politik Islam.

\section{Partai Politik Islam dan akar perpecahan}

Demokrasi terpimpin Soekarno memang tidak memberi peluang untuk perbedaan pendapat dalam menghadapi isu-isu politik penting. Demokrasi terpimpin ditafsirkan oleh sebagian pemimpin muslim sebagai penyimpangan dari prinsip-prinsip perjuangan dalam Islam. Tapi pemimpin muslim yang turut dalam sistim tersebut berpendapat bahwa partisipasi mereka bila dilihat dari sisi pandangan politik, hanyalah suatu sikap realistis dan pragmatis dalam menghadapi sistim otoriter.

Pada saat itu, Partai Masyumi dipaksa membubarkan diri karena dianggap oposisi dan menentang revolusi. Presiden Soekarno menuduh bahwa Masyumi berada dibelakang pemberontakan-pemberontakan yang terjadi dibeberapa daerah, 
antara lain Sumatera Barat, Aceh, Sulawesi, dan Kalimantan. Daerah-daerah yang memberontak tersebut merupakan kantongkantong Masyumi seperti Natsir, Syafruddin Prawiranegara dan Burhanuddin Harahap, yang dianggap terlibat dalam pemberontakan PRRI di sumatera Barat tersebut, namun Masyumi tidak mengeluarkan sikap atas keterlibatan tersebut. ${ }^{3}$ Mereka memberontak bukan atas nama partai, melainkan atas nama pribadi pemberontakan mereka pun untuk tujuan supaya Soekarno menyadari kekeliruaanya dan kembali ke jalan yang benar dalam melaksanakan pemerintahannya. ${ }^{4}$

Masyumi adalah ujung tombak penegak demokrasi yang hendak dikubur oleh Soekarno melalui Demokrasi terpimpin. Banyak mantan tokoh Masyumi, seperti Mohammad Natsir, Hamka, Burhanuddin Harahap, Mohammad Yunan Nasution, Prawoto Mangkusasmito, Isa Anshari dan Syafruddin Prawiranegara, yang mendekam dalam penjara tanpa proses hukum yang wajar akibat perlawanan terhadap Soekarno. ${ }^{5}$

${ }^{3}$ Ma'arif, Islam Dan Masalah Kenegaraan, hlm. 190

4 Ada cerita menarik dari Ajib Rosidi. Ketika para pemimpin PRRI sudah turun gunung dan mereka kembali ke pangkuan republik, Syafruddin Prawiranegara, bekas perdana menteri PRRI menyerahkan emas seberat $29 \mathrm{~kg}$ kepada pemerintah RI. Emas tersebut diterima oleh Gubernur BI ketika Itu, soemarno. Menurut Syafruddin, emas itu dahulunya digunakan sebagai bekal bagi perjuangan PRRI dan disimpan oleh Syafruddin di tempat yang tidak diketahui oleh siapapun (lihat Ajip Rosidi, Kebesaran Muhammad Natsir dalam Endang Saifuddin Ansari dan Muhammad Amien Rais, Eds. Pak Natsir 80 Tahun Buku Pertama Pandangan dan Penilaian Generasi Muda (Jakarta: Media Dakwah, 1988) hlm, 32. Kalau Syafruddin dan tokoh-tokoh Masyumi lainnya memberontak karena kepentingan-kepentingan pribadi atau golongan mustahil ia akan menyerahkan harta yang sangat berharga tersebut kepada pemerintah.

5 Sebenarnya bukan hanya tokoh-tokoh Masyumi yang ditahan pada masa pemerintahan soekarno. Tokoh-tokoh PSI, karena menentang kebijakan Soekarno juga ikut ditahan. Diantaranya adalah Sutan Syahrir dan Subadio Sastrosatomo. Bagaimana proses penahanan, suka duka dan penderitaan para tahanan politik Soekarno dilukiskan oleh Yunan Nasution dalam karangannya 
Masyumi adalah partai politik Islam modernis yang memiliki pemikiran politik dan mekanisme organisasi yang teratur dan modern. Masyumi tidak terlalu terikat pada doktrindoktrin politik Sunni yang sering akomodatif terhadap penguasa. Karena itu, dalam kamus Masyumi tidak ada konsep kepatuhan kepada penguasa yang despotik, sebagaimana dirumuskan oleh pemikir-pemikir Sunni klasik dan pertengahan seperti AlMawardi dan Ibn Taimiyah. Bagi Masyumi, etika politik dan penegakan cita-cita demokrasi adalah cermin dari cita-cita politik Islam.

Sementara Partai NU sebaliknya bersikap menyesuaikan diri dengan demokrasi ala Soekarno. Mereka bersikap akomodatif sehingga bisa hidup berdampingan dengan Soekarno dan bertahan dalam demokrasi terpimpinnya Soekarno. NU adalah partai yang paling besar diantara ketiganya. Karena dapat dianggap sebagai pendukung utama gagasan Soekarno. Bahkan NU menikmati sekali iklim politik yang diciptakan Soekarno dengan sistim Nasakomnya.

Tokoh-tokoh NU yang ikut ambil bagian dalam demokrasi terpimpin antara lain adalah KH. Idham Chalid, K.H. Achmad Sjaikhu, dan K.H. Saifuddin Zuhri. ${ }^{6}$ K.H. Idham Chalid mengatakan bahwa "masuk dalam sistim demokrasi terpimpin adalah sesuai dengan hukum Allah". Sementara K.H. Achmad Sjaikhu berpendapat bahwa "masuk dalam sistem demokrasi

yang berjudul "Kenang-Kenangan Di Belakang Terali Besi Di Zaman Orla (jakarta: Bulan bintang, 1967), lihat juga dalam Muhammad Iqbal dan Amin Husein Nasution, Pemikiran Politik Islam Dari Masa klasik Hingga Indonesia Kontemporer (Jakarta: Kencana Prenada Media Group, 2010), hlm, 269

6 Tidak semua tokoh politik dari NU mendukung kebijakan demokrasi terpimpin ini. Paling tidak ada tokoh-tokoh seperti Imron Rosjadi dan K.H. Muhammad Dachlan tercatat sebagai penentang gagasan demokrasi terpimpin. Namun mereka kalah suara dengan mayoritas NU lainnya yang menghendaki bergabung dalam demokrasi terpimpin. Imron Rosjadi sendiri juga dipenjara oleh rezim Orla tersebut. Lihat Ma'arif, Islam Dan Politik Di Indonesia, hlm. 64 
terpimpin adalah ijtihad politik pihak pesantren". Adapun K.H. Saifuddin Zuhri adalah tokoh NU yang bertahan menjadi Menteri Agama pada era demokrasi terpimpin. Selain pembenaran tersebut, untuk mendukung pandangan dan pendirian, NU menggunakan kaidah-kaidah ushul fiqh. Diantaranya adalah kaidah "ma laa yudraku kulluhu laa yutaraku ba'dhuh" (sesuatu yang tidak dapat diperoleh secara utuh "100\%", jangan di tinggalkan meskipun hanya diperoleh sebagian saja). Karena itu bagi NU masuk ke dalam sistim demokrasi terpimpin lebih baik dan akan lebih mudah mewarnainya daripada berada di luar sistim. ${ }^{7}$

Namun demikian antara NU dan Soekarno sudah terjalin hubungan yang baik sekali. Antara keduanya seakan akan saling membutuhkan. Bahkan NU, bersama-sama partai Islam lainnya yang mendukung demokrasi terpimpin serta pendukungpendukung Soekarno dari pihak nasionalis dan komunis. Pada sidang MPRS 18 Mei 1963 mengangkat Soekarno menjadi presiden seumur hidup. Ini tentu suatu bentuk penyimpangan dari UUD 1945. NU, dengan juru bicara Sjaikhu, mencari dalil agama sebagai pembenaran sikap mereka. ${ }^{8}$

Dalam hal ini NU menggunakan paradigma politik sunni klasik untuk mempertahankan pendirian mereka. Ahmad Sjaikhu menggunakan tiga pertimbangan; pertama, pertimbangan politik. Bagi NU, betapa luar biasanya jasa Soekarno bagi perjuangan kemerdekaan Indonesia. Berdasarkan prestasi ini, sudah selayaknya Soekarno memperoleh kehormatan tertinggi. kedua, pertimbangan revolusioner. Dalam hal ini, Sjaikhu membandingkan Soekarno dengan Nabi Muhammad saw, yang telah memimpin revolusi di Jazirah Arabia. Seperti di kutip Ma'arif, Syaikhu menyatakan :

7 Muhammad Iqbal dan Amin Husein Nasution, Pemikiran Politik Islam Dari Masa klasik Hingga Indonesia Kontemporer (Jakarta: Kencana Prenada Media Group, 2010), hlm, 269

${ }^{8}$ Ma'arif, Islam Dan Politik Di Indonesia, hlm. 110-111

Sangaji Jurnal Pemikiran Syariah dan Hukum 
"Sebagaimana dengan Nabi Muhammad Saw. 13 abad yang lalu dalam memimpin revolusi bangsa-bangsa Arab yang dahulunya bodoh itu, mengalami rintangan-rintangan dan bahaya-bahaya yang ditujuakan kepada diri beliau dan umat serta ajaran-ajarannya, begitu pula kini dalam saat-saat dimana bangsa indonesia di bawah pimppinan Bung Karno sedang menyelesaikan revolusinya" ${ }^{\prime 9}$

Ketiga, pertimbangan Agama. Menurut Sjaikhu, sepanjang sejarah Islam tidak didapati bahwa kepala negara dipilih dan menjalankan tugasnya dibatasi oleh waktu lima atau sepuluh tahun. Kepala negara dapat menjalankan tugas-tugasnya selama masih memenuhi syarat-syarat. Ini berarti bahwa kepala negara boleh berkuasa seumur hidup. Sjaikhu yakin bahwa panglima besar revolusi presiden Soekarno memiliki syarat-syarat demikian. ${ }^{10}$

Bagi NU sikap melawan kekuasaan Soekarno jauh lebih berbahaya daripada menerima tanpa protes. Sikap akomodatif ini diambil untuk menekan resiko seminimal mungkin. Adalah hal yang sia-sia melawan Soekarno yang ketika itu sangat kuat dengan dukungan sepenuhnya militer (angkatan Darat). Oposisi bukan hanya tindakan yang sia-sia, dalam hal ini NU menggunakan kaidah agama akhaff al-dhararayn (memilih resiko yang paling kecil diantara dua resiko).

Namun yang jelas, apa pun yang dipilih oleh partai-partai Islam, menolak atau menerima demokrasi terpimpin, keduaduanya sama-sama hancur. Masyumi lebih dahulu bubar setahun setelah Soekarno mengeluarkan dekritnya. Sementara NU yang sempat menikmati kekuasaan akhirnya juga ikut terjungkal dari panggung sejarah politik indonesia modern bersamaan dengan kegagalan pemberontakan PKI tahun 1965.

${ }^{9}$ Ma'arif, Peta Bumi Intelektualisme Islam Di Indonesia, hlm, 184

${ }^{10}$ Ibid., hlm. 185 


\section{Politik Islam; Kristalisasi dan Kolaboratif}

Ahmad Syafi'i Maarif membagi era demokrasi terpimpin yang berumur hingga September 1965 ini menjadi periode proses kristalisasi (hingga Desember 1960) dan periode kolaborasi (hingga pecahnya pemberontakan G-30-S/PKI 1965). ${ }^{11}$

\section{Proses Kristalisasi}

Setelah Dekrit 5 Juli 1959, Soekarno mengumumkan kabinetnya yang baru menggantikan kabinet Djuanda ${ }^{12}$ pada 6 Juli 1959. Dalam kabinet ini, Djuanda tetap diberi posisi penting sebagai menteri pertama yang tugasnya tidak berbeda dengan perdana menteri. ${ }^{13}$ Kabinet inilah yang bertugas melaksanakan gagasan Soekarno dalam bentuk demokrasi terpimpin. sekitar enam setengah tahun sistim ini beroperasi dalam sejarah kontemporer indonesia, secara politik umat Islam tidak saja berbeda pandangan, bahkan berpecah-belah pada saat berhadapan dengan sistim yang diciptakan oleh Soekarno. Pilihan untuk turut atau tidak turut dalam suatu sistim kekuasaan telah membela umat menjadi dua kubu yang saling berhadapan, sedangkan posisi politik mereka secara nasional sudah tidak diperhitungkan lagi.

Pada bulan-bulan pertama pelaksanaan Demokrasi terpimpin terlihat proses kristalisasi yang cepat antara pendukung dan penentang terhadap Demokrasi gaya baru ini. Secara makro, siapa yang mendukung akan dibiarkan hidup, sedangkan yang menentang harus disingkirkan. Secara mikro, dikalangan umat Islam, proses kristalisasi juga menjadi

11 Maarif, Islamic Politics under Guided Democracy in Indonesia, diterjemahkan ke dalam bahasa Indonesia berjudul Islam dan Politik di Indonesia pada Demokrasi Terpimpin (1959-1965), (Yogyakarta: IAIN Sunan Kalijaga Press, 1988).

12 Kabinet Djuanda adalah kabinet peralihan dari periode Demokrasi Parlementer ke Demokrasi Terpimpin.

13 J.D. Legge, Soekarno: A. Political Biography (New York, Washington: Praeger Publisher, 1972), hlm. 311

Sangaji Jurnal Pemikiran Syariah dan Hukum 
kenyataan. Pihak yang ikut serta dalam demokrasi ciptaan Soekarno dapat turut serta dalam jaringan kekuasaan, sekalipun sebagai peserta pinggiran. Sedangkan pihak yang melawan, bukan saja disingkirkan dari lembaga-lembaga politik formal, tapi juga partai mereka dibubarkan, dan tokohtokoh puncak mereka di penjarakan tanpa proses pengadilan. ${ }^{14}$

Dalam majelis konstituante, partai-partai Islam pada umumnya mampu menyatukan persepsi dalam memperjuangkan Islam "Piagam Jakarta" sebagai dasar negara. Tapi di DPR, partai-partai Islam belum memiliki bahasa yang sama dalam menilai perubahan politik yang sedang berlangsung. Lemahnya Sikap politik liga muslim (NU, PSII, dan Perti) terhadap move Soekarno dan partai Masyumi semakin terpojok terus melakukan perlawanan terhadap gagasan dan pelaksanaan Demokrasi terpimpin. Dimata Masyumi sistem demokrasi terpimpin dianggap tidak tepat untuk diterapkan di Indonesia. Sementara NU tetap memutuskan untuk masuk dalam sistem demokrasi terpimpin, betapapun kecil keuntungannya yang akan diraih. NU juga berpendapat bahwa keikutsertaan dalam sistem demokrasi terpimpin adalah sikap realistis dan pragmatis. Di samping itu kebijakan politik yang diambil oleh NU lebih mengutamakan harmoni atau ishlahil ummah (untuk kesejahteraan rakyat) lahir dan batin. ${ }^{15}$

Setelah demokrasi terpimpin berjalan sekitar sembilan bulan, Soekarno membubarkan parlemen hasil pemilihan umum 1955 itu pada 20 Maret 1960. Kemudian ia membentuk DPRGR (Dewan Perwakilan Rakyat Gotong Royong), dimana Masyumi dan PSI tidak diikutsertakan. Pembentukan DPRGR

14 Ahmad Syafi'i Ma'arif, Islam dan Politik Teori Belah Bambu Masa Demokrasi Terpimpin (1959-1965) (Jakarta: Gema Insani Press, 1996), hlm. 50

15 Tim PBNU, Benturan NU - PKI 1948-1965 ( Jakarta: 2013) hlm. 32 
ternyata mempercepat proses kristalisasi dikalangan umat Islam di indonesia. Sebagai partai yang dikategorikan sebagai penghalang revolusi, Masyumi memang tidak sesuai dimasukan dalam DPRGR. Partai Masyumi dituduh sebagai partai yang turut mendalangi pemberontakan PRRI-Permesta, sekalipun secara hukum tuduhan ini tidak beralasan.

Sementara NU yang menerima eksistensi DPRGR dalam rangka menegakkan prinsip amar ma'ruf nahi munkar, dengan harapan bertambahnya perwakilan umat Islam dalam DPRGR secara keseluruhan agar seimbang dengan perwakilan golongan lain. ${ }^{16}$ Sementara Dalam DPRGR yang dibentuk oleh Soekarno umat Islam hanya 67 kursi, nasionalis 94 kursi, dan komunis 81 kursi. ${ }^{17}$

Partai Masyumi dianggap duri dalam daging yang mengganggu "jalannya revolusi" dan harus disingkirkan. Masyumi adalah ujung tombak penegak demokrasi yang hendak dikubur Soekarno melalui demokrasi terpimpin. Soekarno mengambil sikap tegas untuk membungkam tokohtokoh Masyumi. Mohammad Natsir, Hamka, Burhanuddin Harahap, Mohammad Yunan Nasution, Prawoto Mangkusasmito, Isa Anshari dan Sjafruddin Prawiranegara, yang mendekam dalam penjara tanpa proses hukum yang wajar. $^{18}$

16 Duta Masyarakat, 17 Mei 1960, hlm. 1 dalam Ahmad Syafi'i Ma'arif, Islam dan Politik, hlm. 58

17 S.M. Amin, Indonesia di Bawah rezim Demokrasi Terpimpin (Jakarta: Bulan Bintang, 1967), hlm. 50

18 Sebenarnya bukan hanya tokoh-tokoh Masyumi yang ditahan pada masa pemerintahan Soekarno. Tokoh-tokoh PSI, karena menentang kebijakan Soekarno, juga ikut ditahan. Di antara mereka adalah Sutan Syahrir dan Subadio Sastrosatomo. Bagaimana proses penahanan, suka duka, dan penderitaan para tahanan politik Soekarno dilukiskan oleh Yunan Nasution dalam karangannya berjudul Kenang-Kenangan di Belakang Terali Besi di Zaman Rezim Orla, (Jakarta: Bulan Bintang, 1967).

Sangaji Jurnal Pemikiran Syariah dan Hukum 
Dalam politik, kelompok modernis dan tradisionalis saling berkompetisi untuk mengungguli. Masyumi dapat dikatakan lebih unggul daripada NU, terutama pada periode 1950-an awal. Meskipun pada awalnya NU merupakan salah satu sayap terpenting dalam Masyumi pada 1952, dalam Muktamar NU ke-19 di Palembang, NU memutuskan untuk keluar dari Masyumi dan membuat partai sendiri. Menurut Maarif, keputusan ini diambil karena NU tidak mendapat posisi penting dalam struktur kepengurusan Masyumi. Apalagi pada 1952 tersebut posisi pimpinan Partai Masyumi beralih dari Soekiman Wirjosendjojo ke tangan Mohammad Natsir.

Selain itu, Masyumi adalah partai politik Islam modernis yang memiliki pemikiran politik dan mekanisme organisasi yang teratur dan modern. Masyumi tidak terlalu terikat pada doktrin-doktrin politik Sunni yang sering akomodatif terhadap penguasa. Karena itu, dalam kamus Masyumi tidak ada konsep kepatuhan kepada penguasa yang despotik, sebagaimana dirumuskan oleh pemikir-pemikir Sunni klasik dan pertengahan seperti Al-Mawardi dan Ibn Taimiyah. Bagi Masyumi, etika politik dan penegakan cita-cita demokrasi adalah cermin dari cita-cita politik Islam. Para tokoh Masyumi sadar sepenuhnya bahwa pilihan mereka akan menghadapi tembok tebal kekuasaan dan kelompokkelompok yang memanfaatkan situasi dan keadaan demikian. ${ }^{19}$

Perpecahan di tubuh partai-partai Islam dimanfaatkan oleh Soekarno. Soekarno membela NU dan partai-partai tradisional lainnya sebagai salah satu pilar penopang kekuasaannya, dan membubarkan Masyumi sebagai oposisi berbahaya bagi kelangsungan kekuasaannya.

${ }^{19}$ Mohammad Parmudi, Islam dan Demokrasi..., hlm. 137 


\section{Periode Kolaboratif}

Periode kolaboratif, partai-partai Islam yang mengikuti alur Demokrasi Terpimpin yakni partai NU dan partai-partai tradisionalis lainnya, doktrin politik Sunni klasik sangat berperan dalam mengarahkan perilaku politik mereka. Bersatu dengan politik Nasakom Soekarno mendapat pembenaran dari doktrin politik tokoh-tokoh Sunni masa klasik dan pertengahan. Ini merupakan kesempatan bagi NU dan partai-partai politik tradisional untuk berbuat lebih banyak. Apalagi selama ini NU kurang dapat mengekspresikan sikap politik mereka. Masuknya NU dan partai-partai politik tradisionalis Islam lainnya ke dalam struktur kekuasaan yang dibangun Soekarno merupakan kemenangan kelompok tradisionalis atas modernis.

Pada periode ini partai-partai Islam dapat dikatakan sedang berada dibawah pengaruh kuat NU. Fenomena tersebut nampak pada perilaku politik NU: pertama, strategi pokok NU dalam politik yang dikaitkan dengan doktrin pesantren yang menjadi rujukan utama mereka. Strategi dan taktik perjuangan politik NU tidak dapat dipisahkan dari pengaruh kuat pesantren dalam arti konservatisme Islam, NU sering dilukiskan sebagai pesantren dalam politik. ${ }^{20}$

Kedua, karakteristik hubungan NU dan Soekarno. Ketiga, iklim persaudaraan umat dalam kaitannya dengan perikau politik partai-partai Islam. Keempat, masa akhir demokrasi terpimpin dan sikap NU serta partai-partai Islam yang lain terhadapan. Kelima, kehancuran demokrasi terpimpin serta tragedi politik yang dialami PKI dan Bung Karno.

Analisis tentang perilaku politik NU dari budaya pesantren sebagaimana yang dikatakan oleh Zamakhsyari

${ }^{20}$ Kenneth E Ward, The 1971 Election in Indonesia; an east java case Study (Victoria: Centre od Southeast Asian Studies Monash University, 1974), hlm. 91.

Sangaji Jurnal Pemikiran Syariah dan Hukum 
Dhofier menjadi penghubung antara Islam tradisional dengan dunia nyata, ${ }^{21}$ suatu posisi spiritual yang hampir-hampir tidak memberikan kebebesan kepada santrinya berpikir mandiri. Ungkapan "tanpa Kiai Wahab bukan lagi Nahdhatul Ulama" 22 hanya semakin memperkuat tesis bahwa seorang Kiai yang dipercayai memiliki kharisma adalah seorang yang berada dalam posisi untuk memberi "kata putus" dalam memecahkan suatu persoalan krusial dalam budaya pesantren. harus dicatat bahwa pesantren pada umumnya dan pesantren yang berada di bawah pengaruh NU khususnya, otoritas kiai begitu dominan dan sangat dihormati. Para santri merasa terikat dengan kiai sepanjang hidupnya, setidaknya sebagai sumber inspirasi dan bantuan moral bagi kehidupan individual mereka. ${ }^{23}$

Doktrin pesantren dalam implemnetasi perilaku politik praktis pada periode demokrasi terpimpin. Sebagaimana diketahui bersama bahwa NU merupakan gerakan para ulama. Peran ulama dalam menangani masalah politik adalah suatu peran yang serba baru bagi mereka, karena pada saat NU masih bertahan dalam masyumi, peran itu lebih dimainkan oleh kelompok intelektual hasil didikan barat yang

21 Zamakhsyari Dhohifer, Tradisi Pesantren: Studi Tentang Pandangan Hidup Kiai (Jakarta: LP3ES, 1982), hlm. 177

22 "adapun peranan NU tidak dapat dipisahkan dengan peranan yang dilakukan oleh Kiai Wahab. Mudah disimpulkan bahwa gerak harkat Kiai Wahab mencerminkan gerak-joang NU. Ini tidak berarti tokoh-tokoh lain dalam NU tidak mempunyai peranan - soalnya karena peranan Kiai Wahab sangat menentukan, demikian menentukan sehingga apabila seluruh pimpinan bergabung tetapi minus Kiai Wahab maka keputusan tidak dapat diambil. Tanpa Kiai Wahab bukan lagi NU". Dalam saifuddin Zuhri, KH Abdulwahab Chasbullah: Bapak dan Pendiri Nahdlatul Ulama (Jakarta: Yamunu, 1972), hlm. 69. Lihat juga Ahmad Syafi'i Ma'arif, Islam dan Politik Teori Belah Bambu Masa Demokrasi Terpimpin (1959-1965) (Jakarta: Gema Insani Press, 1996), hlm.81-82

${ }^{23}$ Abdurrahman Wahid, "Pesantren Sebagai Subkultur" dalam M. Dawam Rahardjo (ed) Pesantren dan Pembaharuan (Jakarta: LP3ES, 1974), hlm. 42-43 
berorientasi Islam. Setelah NU muncul sebagai partai politik, para ulamalah yang memegang posisi pengambil keputusan, sementara kaum intelektual yang jumlahnya sangat kecil hanya berperan sebagai pendamping para ulama. ${ }^{24}$

Konsep sesepuh atau tetua yang dijadikan dasar oleh Soekarno untuk tampil sebagai penguasa tertinggi diatas pentas politik nasional. Konsep politik paternalistik ini merupakan bagian penting dari sub kultur Jawa tentang hubungan bapak-anak dalam sebuah keluarga besar bangsa indonesia. Dalam terma Soekarno, konsep bapak di sini adalah seorang tetua yang serba bijak, yang tidak mendiktatori tapi memimpin dan mengayomi. Hal demikian juga terjadi pada subkultur pesantren, dimana posisi kiai dipandang begitu agung secara spritual. Pada masa demokrasi terpimpin, Soekarno adalah sesepuh bangsa indonesia secara keseluruhan, sementara dalam kubu NU, Kiai Wahab dan Kiai Idham Chalid adalah figur-figur puncak yang menentukan secara mutlak warna politik NU. Karakteristik ini berangkat dari doktrin ikraman lil-kabir warrahmah lis-shagier (memuliakan yang tinggi dan mengasihi yang rendah). ${ }^{25}$ Bila doktrin ini kita kaitkan dengan perilaku politik NU, maka tokoh-tokoh seperti kiai Wahab dan Kiai Idham adalah pihak yang tinggi yang harus dimuliakan dan dipatuhi perintah-perintahnya dalam masalah agama dan politik. Doktrin ini dengan sendirinya telah memperkuat posisi para sesepuh ulama yang loyal kepada presiden Soekarno. Dengan demikian, tokoh-tokoh NU yang berada dalam posisi yang rendah tidak akan benyak berkutik menghapi Soekarno, sekalipun mereka misalnya mengerti

24 Ibid., hlm. 87

25 Doktrin ini dalam buku anggaran dasar NU merupakan bagian dari tugas Syuriah dalam rangka menguatkan tali persaudaraan di kalangan para ulama NU. Lihat Buku Anggaran Dasar, hlm. 14

Sangaji Jurnal Pemikiran Syariah dan Hukum 
bahwa pemerintahan Demokrasi terpimpin adalah pemerintahan tanpa demokrasi sikap taat yang di tunjukkan oleh sebagian besar warga NU terhadap pihak tinggi sebenarnya merupakan warisan pemikiran politik Islam klasik yang tidak memberikan kemerdekaan kepada umat untuk bersuara lain dengan penguasa. ${ }^{26}$

Posisi politik NU khususnya dan partai-partai Islam umumnya dalam kerja sama Nasakom. Nasakom adalah singkatan dari Nasionalis, Agama dan Komunis. Formula ini dipopulerkan Soekarno dan pengikutnya sejak akhir 1960. Target sebenarnya yang hendak diraih Soekarno dengan Nasakom ialah agar PKI dimasukan dalam kabinet, suatu keinginan yang telah lama ia pendam. Keinginan ini tidak pernah menjadi kenyataan seperti yang didambakannya, sekalipun tiga serangkai tokoh puncak PKI: D.N. Aidit, M.H. Lukman, dan Nyoto dimasukan dalam kabinet pada 1962, tapi tanpa portofolio. Posisi politik ini jelas tidak memuaskan Soekarno, apalagi PKI.'namun itulah kenyataan yang dapat dicapai PKI pada waktu itu karena oposisi terhadap ide tersebut cukup berat. Oposisi keras datang dari angkatan darat. dan partai politik, dalam hal ini NU sebagai penentang utama bagi masuknya PKI dalam pemerintahan, setelah Masyumi tidak ada. ${ }^{27}$

Masuknya partai-partai Islam dalam kerja sama Nasakom, secara formal telah dianggap revolusioner. Pada masa itu, pertimbangan apakah suatu kekuatan politik revolusioner atau kontra revolusioner, akan sangat ditentukan oleh sikapnya terhadap Nasakom. Semakin vokal suatu kekuatan politik atau siapapun dalam meneriakkan Nasakom,

26 Ahmad Syafi'i Ma'arif, Islam dan Masalah Kenegaraan: Studi tentang percaturan dalam Konstituante (Jakarta: LP3ES, 1985), hlm. 26-28

27 S. Tasrif, "Situasi Kaum Intelektuil di Indonesia", Budaya Jaya, No. 4. Vol. 1 Sept. 1968) hlm. 201 dalam Ahmad Syafi'i Ma'arif, Islam dan Politik... hlm. 92 
ia akan semakin dikategorikan sebagai revolusioner, meskipun mungkin teriakan itu hanya sekadar cara menyelamatkan diri dari kecurigaan Soekarno dan PKI. Karena Islam dipandang sebagai salah satu unsur Nasakom dengan NU sebagai wakil utamanya, maka partai ini tidak perlu cemas akan tersingkir dari logika revolusioner Soekarno, asal pandai-pandai menari sesuai dengan irama politik Nasakom. Partai-partai Islam yang lain dalam menghadapi berbagai isu politik lebih banyak meniru gaya NU sebagai kekuatan Islam terbesar saat itu.

Pada permulaan 1961, doktrin pesantren yang dianut NU dalam berpolitik sebagai strategi pokoknya. Dibekali asumsi dasar bahwa berada didalam akan lebih afdal ketimbang berada diluar, apalagi berada di dalam itu dipadati oleh unsur agama, Zuhri membantah pendapat beberapa tokoh Islam bahwa Islam dalam bahaya. Lewat Duta Masyarakat, Sekjen NU itu menyatakan bahwa Islam tidak dalam bahaya. ${ }^{28}$ Kemudian dikutipnya pernyataan presiden Soekarno "bahwa pemerintah tidak membahayakan Islam, sebaliknya malah menagungkan agama". ${ }^{29}$

\section{Kesimpulan}

Dari uraian diatas dapat ditarik kesimpulan bahwa sistim politik Islam pada masa demokrasi terpimpin terbagi menjadi dua periode yaitu periode kristalisasi dan periode kolaborasi. Periode kristalisasi ditandai dengan pemilihan kawan dan lawan, pendukung dan oposisi terhadap kebijakan Soekarno tersebut. Sementara periode kolaborasi ditandai dengan kerja sama partaipartai Islam yang ikut bersama demokrasi terpimpin, termasuk dengan komunis, yang merupakan salah satu pilar penyangganya. Secara makro, siapa yang mendukung akan

\footnotetext{
${ }_{28}$ Duta Masyarakat, 4 januari 1961, hlm. 1

${ }^{29}$ Ibid.
}

Sangaji Jurnal Pemikiran Syariah dan Hukum 
dibiarkan hidup, sedangkan yang menentang harus disingkirkan. Secara mikro, dikalangan umat Islam, proses kristalisasi juga menjadi kenyataan. Pihak yang ikut serta dalam demokrasi ciptaan Soekarno dapat turut serta dalam jaringan kekuasaan, sekalipun sebagai peserta pinggiran. Sedangkan pihak yang melawan, bukan saja disingkirkan dari lembaga-lembaga politik formal, tapi juga partai mereka dibubarkan, dan tokoh-tokoh puncak mereka di penjarakan bertahun-tahun tanpa proses pengadilan. Sementara pada proses kolaborasi, partai-partai Islam umumnya dalam kerja sama Nasakom. Nasakom adalah singkatan dari Nasionalis, Agama dan Komunis.

Masuknya partai-partai Islam dalam kerja sama Nasakom, mereka secara formal telah dianggap revolusioner. Pada masa itu, pertimbangan apakah suatu kekuatan politik revolusioner atau kontra revolusioner, akan sangat ditentukan oleh sikapnya terhadap Nasakom. Semakin vokal suatu kekuatan politik atau siapapun dalam meneriakkan Nasakom, ia akan semakin dikategorikan sebagai revolusioner, meskipun mungkin teriakan itu hanya sekadar cara menyelamatkan diri dari kecurigaan Soekarno dan PKI. Karena Islam dipandang sebagai salah satu unsur Nasakom dengan NU sebagai wakil utamanya, maka partai ini tidak perlu cemas akan tersingkir dari logika revolusioner Soekarno, asal pandai-pandai menari sesuai dengan irama politik Nasakom. Partai-partai Islam yang lain dalam menghadapi berbagai isu politik lebih banyak meniru gaya NU sebagai kekuatan Islam terbesar saat itu. 


\section{Daftar Pustaka}

Karim, M. Abdullah, Wacana Politik Islam Kontemporer, Yogyakarta; Suka Press, 2007

Iqbal, Muhammad, Pemikiran Politik Islam Dari Masa Klasik Hingga Indonesia Kontemporer, Jakarta; Kencana Prenada Media Group, 2010

H.A. Notosoetardjo, Proses kembali kepada Jiwa Proklamasi 1945; Apakah Demokrasi Terpimpin itu? Jakarta: Lembaga Penggali dan Penghimpun Sedjarah Revolusi Indonesia, 1964

Nasution, Yunan, "Kenang-Kenangan Di Belakang Terali Besi Di Zaman Orla Jakarta: Bulan bintang, 1967

Ida, Laode, Anatomi Konflik NU, Elit Islam dan Negara Jakarta: Sinar Harapan, 1996

Ma'arif, Ahmad Syafi'i, Islam Dan Masalah Kenegaraan: Studi Tentang Percaturan dalam Konstituante, Jakarta: LP3ES, 1985 Islam dan Politik Teori Belah Bambu Masa Demokrasi Terpimpin (1959-1965), Jakarta: Gema Insani Press, 1996

Legge, J.D., Soekarno: A. Political Biography (New York, Washington: Praeger Publisher, 1972)

S.M. Amin, Indonesia di Bawah rezim Demokrasi Terpimpin, Jakarta: Bulan Bintang, 1967

E Ward, Kenneth, The 1971 Election in Indonesia; an east java case Study, Victoria: Centre od Southeast Asian Studies Monash University, 1974

Dhohifer, Zamakhsyari, Tradisi Pesantren: Studi Tentang Pandangan Hidup Kiai, Jakarta: LP3ES, 1982

Zuhri, Saifuddin, KH Abdulwahab Chasbullah: Bapak dan Pendiri Nahdlatul Ulama, Jakarta: Yamunu, 1972

Wahid, Abdurrahman, "Pesantren Sebagai Subkultur" dalam M. Dawam Rahardjo (ed) Pesantren dan Pembaharuan Jakarta: LP3ES, 1974

Sangaji Jurnal Pemikiran Syariah dan Hukum 
S. Tasrif, "Situasi Kaum Intelektuil di Indonesia", Budaya Jaya, No. 4. Vol. 1 Sept. 1968

Duta Masyarakat, 17 Mei 1960, 